\section{The Crystal Structure of $\mathrm{K}_{3} \mathrm{Mn}(\mathrm{CN}){ }_{5} \mathrm{NO} \cdot 2 \mathrm{H}_{2} \mathrm{O}$}

AINA TULLBERG and NILS-GÖSTA VANNERBERG

Department of Inorganic Chemistry, University of Gothenburg and Chalmers Institute of Technology, Gothenburg, Sweden

$\mathrm{T}$ he mode of coordination of the nitrosyl group in transition metal complexes has been the object of considerable discussion in recent years. An extensive programme of research into the crystal structures of the transition metal nitrosyls has therefore been started at this Department. A series of pentacyanonitrosyl metal ions are among those compounds which have been studied, the structure of the first member, $\mathrm{K}_{8} \mathrm{Cr}(\mathrm{CN})_{5} \mathrm{NO}$ having been determined by Vannerberg. 1 The structure of $\mathrm{K}_{2} \mathrm{Mn}(\mathrm{CN})_{5} \mathrm{NO} \cdot 2 \mathrm{H}_{2} \mathrm{O}$ has now also been determined and is in the process of $r e$. finement.

$\mathrm{K}_{3} \mathrm{Mn}(\mathrm{CN})_{5} \mathrm{NO} \cdot 2 \mathrm{H}_{2} \mathrm{O}$ was prepared according to Cotton, Monchamp, Henry and Young's modifieation ${ }^{2}$ of the method due to Hieber, Nast and Proeschel, ${ }^{3}$ whereby $\mathrm{K}_{2} \mathrm{Mn}(\mathrm{CN})_{0}$ is treated with an alkaline solution of hydroxylamine.

The crystal structure of $\mathrm{K}_{3} \mathrm{Mn}(\mathrm{CN})_{5} \mathrm{NO}$. $2 \mathrm{H}_{2} \mathrm{O}$ has been investigated by single crystal methods. The unit cell has the dimensions $a=17.60 \AA, b=7.01 \quad$, $c=11.49 \AA, \beta=118^{\circ}$. The space group proved to be $C c$. The density was determined to be $1.9 \mathrm{gm} / \mathrm{cm}^{3}$. Consequently there are four formula units per unit cell. The atomic parameters listed in Table 1 have been found by means of three. dimensional Patterson and Fourier syntheses.

The manganese atoms are octahedrally coordinated by five cyanide groups and one nitrosyl group. The $\mathrm{Mn}-\mathrm{CN}$ bond
Table 1. Space group $C c$, all atoms occupying $4 a$.

\begin{tabular}{|c|c|c|c|}
\hline Atom & $x$ & $y$ & $z$ \\
\hline Mn & 0.000 & 0.000 & 0.000 \\
\hline $\mathbf{K}$ & 0.251 & 0.143 & 0.364 \\
\hline $\mathbf{K}$ & 0.747 & 0.862 & 0.668 \\
\hline $\mathbf{K}$ & 0.493 & 0.041 & 0.236 \\
\hline CN groun & 0.414 & 0.382 & 0.339 \\
\hline CN group & 0.364 & 0.295 & 0.250 \\
\hline CN group & 0.578 & 0.625 & 0.674 \\
\hline N group & 0.626 & 0.694 & 0.773 \\
\hline $\mathrm{CN}$ group & 0.937 & 0.879 & 0.582 \\
\hline 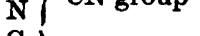 & 0.896 & 0.798 & 0.621 \\
\hline CN group & 0.070 & 0.232 & 0.054 \\
\hline 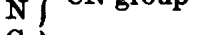 & 0.114 & 0.372 & 0.090 \\
\hline CN group & 0.918 & 0.787 & 0.958 \\
\hline CN group & 0.871 & 0.664 & 0.935 \\
\hline NO group & 0.052 & 0.119 & 0.433 \\
\hline 80 oxp & 0.087 & 0.219 & 0.391 \\
\hline $\mathrm{H}_{2} \mathrm{O}$ & 0.242 & 0.021 & 0.085 \\
\hline & 0.739 & 0.991 & 0.932 \\
\hline
\end{tabular}

distances vary within the range 1.95 and $1.99 \AA$, whereas the $\mathrm{Mn}-\mathrm{NO}$ bond distance is $1.65 \AA$, in accordance with the postulate of Ballhausen and Gray." The distances between the oxygen atoms of the water molecules and the cyanide and nitrosyl groups indicate the presence of hydrogen bonding. An $R$-factor of 0.109 has been obtained and further refinement of the structure is in progress. A complete report of the investigation will be published shortly.

1. Vannerberg, N.-G. Acta Chem. Scand. In press.

2. Blanchard, A. and Magnusson, F. J. Am. Chem. Soc. 63 (1941) 2236.

3. Hieber, W., Nast, R. and Proeschel, E. Z. anorg. allgem. Chem. 256 (1948) 159.

4. Ballhausen, C. J. and Gray, H. B. Inorg. Chem. 2 (1963) 426.

Received April 21, 1966. 